\title{
Explaining entrepreneurial performance of solo self-employed from a motivational perspective
}

\author{
Nardo de Vries • Werner Liebregts • André van Stel
}

\begin{abstract}
This paper investigates the relationship between start-up motivation (opportunity versus necessity) and entrepreneurial performance of an important subset of entrepreneurs, viz., the solo self-employed. We use a unique individual-level panel data set of solo self-employed in the Netherlands (2010-2011) and construct three separate measures derived from the literature to identify necessitydriven solo self-employment. Using annual turnover as measure of entrepreneurial performance, we consistently find that necessity-driven solo self-employed perform worse than opportunity-driven solo self-employed. Still,
\end{abstract}

Electronic supplementary material The online version of this article (https://doi.org/10.1007/s11187-019-00244-8) contains supplementary material, which is available to authorized users.

N. de Vries $(\bowtie)$

School of Business and Economics, Maastricht University, Tongersestraat 53, 6211 LM Maastricht, The Netherlands e-mail: ne.devries@maastrichtuniversity.nl

\section{W. Liebregts}

Jheronimus Academy of Data Science, 's-Hertogenbosch, The Netherlands

\section{W. Liebregts}

Tilburg School of Economics and Management, Tilburg University, Tilburg, The Netherlands

A. van Stel

Trinity Business School, Trinity College Dublin, Dublin, Ireland

A. van Stel

Center for Entrepreneurship, Kozminski University, Warsaw, Poland only a low proportion of necessity solo self-employment may be considered precarious employment, suggesting necessity entrepreneurship is not so worrisome as sometimes assumed. In general, our findings suggest that the borderline between necessity and opportunity entrepreneurship in developed economies may be less clear-cut than previously assumed.

Keywords Solo self-employed - Nature of opportunity · Entrepreneurship $\cdot$ Performance $\cdot$ Start-up motivations

JEL classification $\mathrm{J} 24 \cdot \mathrm{L} 25 \cdot \mathrm{L} 26 \cdot \mathrm{C} 33$

\section{Introduction}

Since the 1980s, many European Union member countries have witnessed an increase in the share of selfemployed in the labor force (Luber and Leicht 2000; Cieslik and Van Stel 2014; Fritsch et al. 2015). This trend is almost entirely explained by an increase in the number of solo self-employed while the share of self-employed with personnel remained relatively stable (OECD 2000; Rapelli 2012; Kitching 2015). In modern economies, many solo self-employed contribute greatly to economic prosperity by enabling client firms to operate in a more flexible and cost-reducing manner and also by introducing innovations to their client firms (Burke 2011 2012; Burke and Cowling 2015). However, self-employment is also often viewed as relatively less productive, making a limited contribution to the economy (Román et al. 2011; 
Henrekson and Sanandaji 2014; Mason and Brown 2014; Stam 2014). These different views on the importance of solo self-employment reflect the huge heterogeneity among self-employed workers in modern economies (CRSE 2017).

An important source of this heterogeneity concerns the start-up motivations of the self-employed (Block and Sandner 2009; Fossen and Büttner 2013). Reynolds et al. (2002) were the first to introduce the concept of opportunity and necessity entrepreneurs based on opposing motives for starting a business. Opportunity entrepreneurs start a new venture to exploit a unique business opportunity, whereas necessity entrepreneurs start a firm because it is the best option available. This distinction comes down to the extent of voluntariness in the decision to become self-employed. It is often assumed that necessity-driven self-employed display less entrepreneurial capabilities and perform worse than their opportunity-driven counterparts. Although this assumption is mainly based on macro-level data and outcomes (e.g., Acs and Varga 2005), empirical evidence at the micro level is now becoming increasingly available. In particular, although opportunity entrepreneurs are typically found to perform better than necessity entrepreneurs (Block and Wagner 2010; Van Stel et al. 2018), the difference is found to be either weak (as in Baptista et al. 2014) or non-robust to the inclusion of human capital measures in regressions explaining entrepreneurial performance (as in Block and Sandner 2009).

The present paper investigates whether the start-up motivation influences entrepreneurial performance of solo self-employed workers. An important element of our analysis will be to explore how many necessity solo self-employed still earn enough to make a living. Even if necessity solo self-employed earn less than their opportunity counterparts, if most of them still can make a decent living, policy concerns about the marginality of a big group in the labor market may be overstated. By comparing annual turnover of necessity solo selfemployed to national low-income standards and the Dutch "at-risk-of-poverty-threshold," we evaluate the extent of precariousness among necessity solo selfemployed in the Netherlands.

Our paper contributes to extant literature in several ways. First, this is the first study that, both theoretically and empirically, distinguishes between start-up motivations in the particular context of solo self-employment. Although the literature on necessity and opportunity entrepreneurship is increasing rapidly (Poschke 2013;
Brewer and Gibson 2014; Block et al. 2015; Darnihamedani and Hessels 2016; Larsson and Thulin 2018), we are the first study applying these concepts in the context of solo self-employment. We will argue that this is an especially suitable context to study opportunity versus necessity entrepreneurship. Second, we use a more refined measure of entrepreneurial performance. Survival, the measure used by Block and Sandner (2009), Baptista et al. (2014), and Caliendo and Kritikos (2009) is a rather crude measure of performance, which is unable to distinguish between marginal entrepreneurs who only just succeed in keeping their business running, and highly successful entrepreneurs. In our paper, we use annual turnover (an indicator close to income) of the solo self-employed as measure of entrepreneurial performance. Third, many different operationalizations of necessity-driven self-employment circulate in the literature. The public and scholarly debate on this subject could benefit from a robust measure of the concept of necessity-driven entrepreneurship. Our paper contributes to the validation of measures of necessity-driven entrepreneurship by using three different operationalizations. Fourth, to the best of our knowledge, we are the first paper that attempts to quantify the extent of precariousness among necessity selfemployed, using an objective poverty benchmark for a developed country.

The rest of the paper is structured as follows. In the next section we provide an overview of the extant literature on solo self-employment and start-up motivation, from which we derive our hypothesis. The data and methodology section describes the data source, the measures used, and the model specifications. In the results section, we discuss the estimation results of the econometric analysis. The final section presents the conclusions and discusses the implications. We also provide suggestions for future research.

\section{Theory and hypothesis}

\subsection{Solo self-employment}

Self-employment covers a wide spectrum of entrepreneurship varying from innovative starters to independent professionals, and from dependent workers (Román et al. 2011) and sole proprietary retailers to employer entrepreneurs. Acknowledging this heterogeneity is important, because certain types of self- 
employed tend to perform better than other types, and show higher rates of productivity (Van Stel and De Vries 2015). Particularly solo self-employed workers are sometimes accused of low productivity (Smeaton 2003; Acs 2006; Stam 2014). It can therefore be argued that the distinction between solo self-employed and employer entrepreneurs is relevant to take into account when investigating start-up motivation and its relationship with entrepreneurial performance. Notwithstanding the large literature on general self-employment (that does not make the distinction with or without employees; e.g., Taylor 1996; Blanchflower and Oswald 1998; Arum and Müller 2004; Baumgartner and Caliendo 2008; Bögenhold and Fachinger 2012), to our knowledge, no research has been carried out that specifically studies start-up motivations of solo selfemployed. Especially when considering performance differences between opportunity and necessity-driven activities, we deem the solo self-employed as a highly relevant group. This is because necessity entrepreneurs are likely to be more often solo self-employed than employer entrepreneur, in part due to lower entry requirements for solo self-employment and policy measures stimulating self-employment. For instance, unemployed founders may be considered more likely to start a (necessity-based) business in craftsmanship or in the services industry, instead of starting capital intensive firms like retail shops or even high-tech spinoffs. In sum, since opportunity and necessity entrepreneurship are likely more evenly distributed within the population of solo self-employed (relative to the population of employer entrepreneurs), we argue that solo selfemployment is an especially suitable context to study opportunity versus necessity entrepreneurship.

Moreover, within the context of solo self-employment, the definition that is used in this study is a narrow one that specifically suits our research topic. Individuals are considered to be solo self-employed if they independently undertake entrepreneurial activities without employing another person. In addition, they have to indicate that he or she mainly offers labor (knowledge, skills, et cetera) instead of selling goods. As such, solo self-employed can be seen as a subgroup of the own account workers, the latter group also containing individuals that mainly sell goods. Our definition of solo self-employment implies that there may be low entry barriers in terms of capital constraints, start-up specific human capital, networks, and information requirements, exposing higher shares of necessity start-ups (Caliendo et al. 2015).
2.2 Necessity versus opportunity-driven

entrepreneurship: a taxonomy of start-up motivations

Reynolds et al. (2002) introduced the dichotomy between opportunity and necessity entrepreneurs in the Global Entrepreneurship Monitor (GEM) of 2001. Since then, much debate has been going on about the possible over-simplification of this dualistic categorization of entrepreneurs' start-up motives (Giacomin et al. 2011; Williams and Williams 2014). Some argue that both opportunity and necessity motives can co-exist at the start of a venture (Caliendo and Kritikos 2009; Dawson and Henley 2012; Williams and Williams 2014). Nevertheless, Dawson and Henley (2012) found that, despite the discussion on the heterogeneity of motivations, the majority of individuals voluntarily point out a single motivating factor for starting a company. Hence, it can be argued that the dichotomy between opportunity and necessity-motivated entrepreneurship is still applicable to the majority of entrepreneurs, but needs further conceptual refinement, and more objective and comprehensive measures.

Despite the clarity of the motivational taxonomy of Reynolds et al. (2002), there is much ambiguity in the empirical evidence due to different operationalizations of the necessity concept. Block and Sandner (2009) present an overview of studies on necessity entrepreneurship in Germany. The shares of necessity entrepreneurship found in these studies vary considerably (from 6.7 to $45.3 \%$ ). These differences are mainly caused by different interpretations of the necessity concept and the use of alternating measures. Some measures are based on the subjective self-classification as defined by GEM. Other measures are based on a more objective but narrower operationalization, like starting out of unemployment, or the degree of voluntariness in leaving a previous paid job. Based on the latter definition of necessity-driven entrepreneurship, Block and Sandner (2009) find a share of $28.7 \%$ in Germany. However, classifying start-ups of previously unemployed as necessity-based is not as straightforward as it seems. Caliendo and Kritikos (2009) present evidence of both opportunity and necessity motives among this type of start-ups. What is still lacking is a measure that is objective and still covers the broad spectrum of startup motives that drive people to become solo selfemployed. One of the contributions of our paper is that we will consider not only measures based on subjective self-classification and unemployment but also a new 
measure that addresses the shortcoming mentioned above. In particular, we will introduce a classification of objective start-up motives, which we then label opportunity or necessity-motive ex-post, so that the respondent is not influenced (also see Dawson and Henley 2012). We will estimate our regression models using all three measures of necessity entrepreneurship, thereby also testing for robustness of our results.

\subsection{Empirical evidence}

There is a growing literature on necessity and opportunity entrepreneurship. Two streams may be identified. A first stream of literature examines socio-psychological and socio-economic determinants of entrepreneurial motivation (Giacomin et al. 2011; Turkina and Thai 2015). A second stream, to which the present research belongs, focuses on performance differentials between the two motivations. Most papers so far focus on the viability of necessity-driven entrepreneurship (Block and Sandner 2009; Baptista et al. 2014; Caliendo et al. 2015). The common and dominant finding in these studies is that individuals that start a venture out of a necessity motive have consistently lower probabilities to remain in self-employment compared with their opportunity counterparts. ${ }^{1}$ Kautonen and Palmroos (2010) suggest that necessity entrepreneurs are more inclined to switch back to paid employment due to a lower satisfaction level associated with a self-employed position. At the micro level, Caliendo and Kritikos (2009) consider three types of entrepreneurs. Next to opportunity and necessity entrepreneurs, they also define a group of entrepreneurs with mixed start-up motives simultaneously. They find that the survival rates of entrepreneurs with mixed start-up motives are significantly higher than those of necessity entrepreneurs, even though both entrepreneurial types have very similar socio-economic characteristics. Block et al. (2015) provide a possible explanation for performance differentials and report that firms founded by necessity entrepreneurs are more likely to pursue a cost leadership strategy and less likely to pursue a differentiation strategy.

\footnotetext{
${ }^{1}$ Poschke (2013) is an exception as he finds that necessity entrepreneurs "are likely to stay in the market" (p. 658).
}

\subsection{Hypothesis}

Entrepreneurs starting out of a necessity motive such as many unemployed face several disadvantages compared with opportunity-driven entrepreneurs (Caliendo et al. 2015). They often face severe credit constraints, in part because of discrimination at the capital market ${ }^{2}$; they suffer from negative stigma effects (discrimination by customers); they have lower self-confidence; and due to the necessity to earn an income, they often take less preparation time, resulting in a lower quality of the business opportunity being pursued and lower business results once the business is running (Caliendo et al. 2015: pp. 167-168). Moreover, Larsson and Thulin (2018) show that subjective well-being of necessity entrepreneurs is lower than that of opportunity entrepreneurs.

Furthermore, necessity entrepreneurs also face disadvantages which are more clearly related to their-on average-lower human capital levels (Poschke 2013). These disadvantages include lower cognitive ability, lower ability to manage employees, lower ability to make a good business planning and strategy, and smaller business and social networks implying limited access to important information regarding the business opportunity. Their lower human capital may also constrain them to pursue high-tech business opportunities. All these disadvantages suggest that firm performance of necessity entrepreneurs will be lower than that of opportunity entrepreneurs.

H1: Necessity solo self-employed display lower
entrepreneurial performance than opportunity solo
self-employed.

\section{Data and methodology}

\subsection{Representative panel of solo self-employed}

We use a unique individual-level panel data from the Panteia/EIM Panel of solo self-employed, ${ }^{3}$ in the Netherlands. This panel measures entrepreneurial

\footnotetext{
${ }^{2}$ Caliendo et al. (2015, p. 167) explain such discrimination as follows: "For instance, unemployed individuals are more likely to have bad debt records, less wealth and less human capital, thus reducing their probability of receiving credit."

${ }^{3}$ For technical details, we refer to online documentation: https://easy. dans.knaw.nl/ui/datasets/id/easy-dataset:55814 (in Dutch).
} 
performance of solo self-employed next to their personal, firm, and job characteristics. This enables us to explore variations in performance across entrepreneurs and over time. The database specifically targets the solo self-employed and consists of annual waves of longitudinal data. Panel members are considered to be solo self-employed if they meet the criteria mentioned in Section 2.1. As soon as they do not meet all of the criteria (e.g., quit their business or hire personnel), or if they cannot be contacted anymore, members drop out of the panel. Data collection is conducted via telephone interviews, which holds the advantage of an active approach. This enhances the reliability of the results and increases control over the representativeness of the sample. The panel is set up according to a stratified sample plan to assure sufficient coverage in all industries, but with random selection within each industry. For our regression analysis, we construct an unbalanced panel data set from two consecutive years (2010 and 2011) containing 1360 unique panel members corresponding to 1803 observations.

\subsection{Panel attrition}

Panel studies typically suffer from panel attrition. That is, individuals that initially participated in one of the waves failed to be interviewed again in subsequent waves. This might be due to a variety of reasons, but it is unlikely that the attrition is completely at random. Without using any formal test, we argue that the attrition bias seems to be limited in case of our panel. For instance, entrepreneurial performance in the panel might be positively skewed because of dropouts who ended their entrepreneurial activities. Then, by definition we are left with a data set containing solo self-employed that perform well (better), leading to a non-response bias. If one of the two types of solo self-employed (opportunity vs. necessity) systematically performs worse, then it is possible that the sample suffers from a selection effect. One way to check for the presence of a non-response bias is to compare the ratio of both types between different waves. Using all three indicator variables, it appears that the ratio of both types is quite constant over time. Moreover, on average both types participate in approximately the same number of waves. This suggests that a possible non-response bias has, at worst, a limited influence on the regression results. ${ }^{4}$ Also, the participation rate, defined as the number of completed interviews as a percentage of successful contacts, is very high, pointing at a high willingness to participate. The active approach certainly helped to create a high sense of loyalty among panelists $(70 \%)$. This can be seen as a measure of the quality of the panel.

\subsection{Measures and descriptive statistics}

\subsubsection{Dependent variable}

Entrepreneurial performance is measured by annual gross turnover as stated by the respondents. This variable is actually a "best estimate" of the current calendar year, but it is deemed a reliable estimate for annual turnover as the data collection has been executed at the end of November each year. The respondents were asked to classify their annual turnover into seven predetermined categories. The turnover category ranging from 25,000 up to 50,000 euro per year represents the mode as well as the median category (see Table 1).

\subsubsection{Indicator variables for necessity solo self-employment}

In existing empirical research, there is no consensus on how to distinguish between opportunity and necessity entrepreneurs. In order to make a better distinction between the two types, and thus shed more light on this scholarly debate, we use three different binary variables denoting necessity solo self-employed. This operationalization also functions as validation and enhances the robustness of the results. The first measure is commonly used in the literature (see Block and Sandner 2009) and identifies those solo self-employed that started out of an unemployment situation (Unemployed). This is a dummy variable indicating whether the respondent was unemployed, incapacitated, and/or entitled to benefits prior to becoming solo self-employed. A second measure resembles the classification of Reynolds et al. (2002) and contains self-proclaimed necessity solo self-employed (Necessity1). This dummy variable is based on the question whether becoming solo self-employed was the only

\footnotetext{
$\overline{{ }^{4} \text { Nevertheless, }}$ descriptive statistics as such may still be slightly biased. For instance, because exiting firms are likely to have had low turnover in case they would have survived, the share of solo selfemployed in the lowest income category may be underestimated to some extent.
} 
Table 1 Frequency and percentage of solo self-employed per annual turnover category by necessity indicator

\begin{tabular}{|c|c|c|c|c|c|c|}
\hline \multirow[t]{2}{*}{ Annual turnover } & \multicolumn{3}{|l|}{ Frequency } & \multicolumn{3}{|l|}{ Percent } \\
\hline & Opportunity & Necessity & Total & Opportunity & Necessity & Total \\
\hline \multicolumn{7}{|l|}{ Unemployed $*$} \\
\hline Less than 10,000 euro & 204 & 23 & 227 & 12.0 & 21.5 & 12.6 \\
\hline 10,000 up to 25,000 euro & 338 & 33 & 371 & 19.9 & 30.8 & 20.6 \\
\hline 25,000 up to 50,000 euro & 433 & 31 & 464 & 25.5 & 29.0 & 25.7 \\
\hline 50,000 up to 100,000 euro & 424 & 10 & 434 & 25.0 & 9.4 & 24.1 \\
\hline 100,000 up to 200,000 euro & 232 & 9 & 241 & 13.7 & 8.4 & 13.4 \\
\hline 200,000 up to 500,000 euro & 56 & 0 & 56 & 3.3 & 0.0 & 3.1 \\
\hline More than 500,000 euro & 9 & 1 & 10 & 0.5 & 0.9 & 0.6 \\
\hline Total & 1696 & 107 & 1803 & 100.0 & 100.0 & 100.0 \\
\hline \multicolumn{7}{|l|}{ Necessity $1 * *$} \\
\hline Less than 10,000 euro & 162 & 65 & 227 & 12.2 & 13.8 & 12.6 \\
\hline 10,000 up to 25,000 euro & 250 & 121 & 371 & 18.8 & 25.6 & 20.6 \\
\hline 25,000 up to 50,000 euro & 326 & 138 & 464 & 24.5 & 29.2 & 25.7 \\
\hline 50,000 up to 100,000 euro & 336 & 98 & 434 & 25.2 & 20.8 & 24.1 \\
\hline 100,000 up to 200,000 euro & 203 & 38 & 241 & 15.3 & 8.1 & 13.4 \\
\hline 200,000 up to 500,000 euro & 46 & 10 & 56 & 3.5 & 2.1 & 3.1 \\
\hline More than 500,000 euro & 8 & 2 & 10 & 0.6 & 0.4 & 0.6 \\
\hline Total & 1331 & 472 & 1803 & 100.0 & 100.0 & 100.0 \\
\hline \multicolumn{7}{|l|}{ Necessity $2 * * *$} \\
\hline Less than 10,000 euro & 164 & 63 & 227 & 12.1 & 14.1 & 12.6 \\
\hline 10,000 up to 25,000 euro & 246 & 125 & 371 & 18.2 & 27.9 & 20.6 \\
\hline 25,000 up to 50,000 euro & 344 & 120 & 464 & 25.4 & 26.8 & 25.7 \\
\hline 50,000 up to 100,000 euro & 343 & 91 & 434 & 25.3 & 20.3 & 24.1 \\
\hline 100,000 up to 200,000 euro & 201 & 40 & 241 & 14.8 & 8.9 & 13.4 \\
\hline 200,000 up to 500,000 euro & 48 & 8 & 56 & 3.5 & 1.8 & 3.1 \\
\hline More than 500,000 euro & 9 & 1 & 10 & 0.7 & 0.2 & 0.6 \\
\hline Total & 1355 & 448 & 1803 & 100.0 & 100.0 & 100.0 \\
\hline
\end{tabular}

$* \chi^{2}=29.618, p=0.000 ; * * \chi^{2}=30.336, p=0.000 ; * * * \chi^{2}=33.635, p=0.000$

option for suitable paid work. The third measure captures necessity solo self-employed based on author classification of a list of reported start-up motives (Necessity2). It is based upon a manual classification of all possible answers to a multiple-choice question asking for the respondents' motives that played a role in their decision to become solo self-employed (see Table A1 in the Online Appendix). The classification is validated by considering the correlation of each answer category with the indicator variable for self-proclaimed necessity solo self-employment. ${ }^{5}$ This type of classification by the researchers is less common due to its labor-intensive character, but has the advantage of objectivity (cf. Dawson and Henley 2012).

\footnotetext{
${ }^{5}$ Respondents could choose several answers from the list in Table A1 in the Online Appendix. In a minority of cases (about 12\%), respondents chose a mix of opportunity and necessity motives. These respondents were removed from the analysis.
}

The share of necessity solo self-employed in the data set depends on which indicator variable is being used. According to the Unemployed indicator, $5.9 \%$ of solo self-employed can be classified as necessity-driven. The self-proclaimed necessity indicator (Necessityl) results in a share of $26.2 \%$ of necessity solo self-employed. The author-classified necessity indicator (Necessity2) yields a share of $24.8 \%$ of necessity-driven solo selfemployed. The overlap between the three different necessity indicators is moderate (see Table A2 in the Online Appendix). This is remarkable but may indicate that the borderline between necessity and opportunity motives in developed economies is less clear-cut than the theoretical literature would lead one to believe. For instance, if a person becomes unemployed, there is a necessity to earn an income again but also an opportunity to perhaps carry out an entrepreneurial idea that the person already had in mind for a long time, but never 
pursued because the opportunity costs were considered too high at the time the person still had a wage job (Kher et al. 2012). A chi-square test gives us a first notion that there is a statistically significant relationship between annual turnover and the type of solo self-employed in terms of their start-up motivations (see Table 1).

\subsubsection{Evaluating the extent of precariousness among necessity solo self-employed}

As mentioned before, we are interested in the income distribution of the necessity solo self-employed. From a social policy perspective, it is particularly interesting to consider the two income groups in our data set below this level, i.e., the categories $0-10,000$ euros and 10,000-25,000 euros, as these income categories are likely to include a percentage of precarious selfemployed workers, i.e., workers who are only just able to make ends meet and who may fall into poverty if they would lose their income from self-employment. In developed economies, like the Netherlands, poverty is not a matter of physical survival but it is rather defined as the lack of income that is necessary to sustain a minimal standard of living considered acceptable (European Council, as cited by Eurostat 2013, p. 2). A country's “at-risk-of-poverty" threshold measures low income in comparison with other residents in that country and is calculated as $60 \%$ of the national median equivalised disposable income after social transfers (Eurostat 2016). ${ }^{6}$ In 2010, it amounts to 12,175 euro for the Netherlands (Eurostat 2016). In our data set, the income category threshold between the lowest and second-to-lowest income group equals a gross annual turnover of 10,000 euro which corresponds to 9522 euro net income after standard tax deductions for self-employment and taking into account the Dutch tax rates. ${ }^{7}$ This falls below the at-riskof-poverty threshold in the Netherlands, so the share

\footnotetext{
${ }^{6}$ The equivalised disposable income is the total income of a household, after tax and other deductions, that is available for spending or saving, divided by the number of household members converted into equalized adults; household members are equalized or made equivalent by weighting each according to their age, using the so-called modified OECD equivalence scale (Eurostat 2016). Importantly, this indicator is defined at the level of persons rather than households.

${ }^{7}$ We performed a crude tax conversion by incorporating standard tax deductibles for the average entrepreneur in the Netherlands (the socalled Zelfstandigenaftrek and MKB-winstvrijstelling). If special support measures for starting entrepreneurs are taken into account, the net income is slightly higher. The calculations are available upon request.
}

of solo self-employed in our lowest income category can be regarded as a lower bound for the share of solo self-employed at risk of poverty. An annual turnover of 25,000 euro on the other hand corresponds to a net income of 19,845 euro, clearly above the at-risk-ofpoverty threshold. Hence, the total share of solo selfemployed in our lowest two income categories is an upper bound for the share of solo self-employed at risk of poverty (assuming no alternative income).

Table 2 shows the income distribution for the subset of solo self-employed without a sufficiently high income to make ends meet if their income from the firm would drop to (almost) zero (selfreported). Note that the total number of solo selfemployed observations drops from 1803 in Table 1 to 888 in Table 2; i.e., half of all solo selfemployed can rely on a sufficiently high alternative income in case their entrepreneurial income would drop to zero. It is now interesting to consider which percentage of all necessity solo selfemployed find themselves in a precarious position, defined as making a low income from solo selfemployment (below the "at-risk-of-poverty" threshold) without having sufficient alternative income sources to make ends meet in case the business income falls out. A lower (upper) bound for this percentage is formed by dividing the number of necessity solo self-employed observations in the lowest (lowest two) income categories in Table 2 by the total number of solo self-employed observations (Table 1). The upper bound for the share of precarious solo self-employed varies between $15.5 \%$ (Necessityl) and $19.6 \%$ (Unemployed), while the lower bound varies between $4.2 \%$ ( $\mathrm{Ne}$ cessity2) and $6.5 \%$ (Unemployed). ${ }^{8}$ Importantly, as the "at-risk-of-poverty" threshold for the Netherlands at the time of our data base (12,175 euro) is much closer to the net disposable income associated with the lower bound of our second lowest income category (9522 euro) compared with the upper bound $(19,845$ euro), it is likely that the share of precarious solo self-employed is actually closer to the estimated lower bound than to the upper bound. Given this information, a ballpark estimate for the share of precarious self-employed

\footnotetext{
${ }^{8}$ For example, the lower and upper bounds for Unemployed are computed as $7 / 107$ and $21 / 107$, respectively, where the numerator is taken from Table 2 and the denominator is taken from Table 1.
} 
among Dutch necessity solo self-employed may be given around 7 to $10 \%{ }^{9}$

\subsubsection{Control variables}

The data set allows us to control for various personal, firm, and job characteristics. Human capital is incorporated in the models via the highest self-stated formal educational level and also via firm age as a proxy for practical learning. Dummy variables were constructed indicating solo selfemployed with a low, medium, or high educational level, where high education refers to a bachelor's or master's degree. $45.6 \%$ of the sample is highly educated. The firm age in our data ranges from zero to 61 years; the mean firm age is slightly more than 9 years. Apparently, the largest part of the firms is relatively recently established. Other control variables include age, gender, and the number of hours per week spent on running the firm and industry dummies. The mean age of the panelists is approximately 48 years. More than two-thirds of the solo self-employed are male. Solo self-employed appear to be hard workers, as more than half of the solo self-employed in the sample spend more than the equivalent of a fulltime job on running their firm. Most of the solo self-employed are active in business services $(15.4 \%)$, followed by construction $(11.9 \%)$ and transport, storage and communication industry (11.4\%). The broader service industry in total covers $55.5 \%$ of the solo self-employed in the sample. A full description of all model variables can be found in Table A3 in the Online Appendix.

\footnotetext{
${ }^{9}$ This can be seen as follows. The lower and upper bounds for the share of precarious solo self-employed are unemployed indicator, $0.065(=7 / 107$, see Tables 1 and 2$)$ and $0.196(=21 / 107) ;$ Necessityl, $0.051(=24 / 472)$ and $0.155(=73 / 472) ;$ Necessity $2,0.042(=19 / 448)$ and $0.158(=71 / 448)$. We have also seen that, in terms of net disposable income, the second income category in our data base runs from 9522 euro to 19,845 euro, and that the "at-risk-of-poverty" threshold is 12,175 euro. Hence, the threshold lies at $25.7 \%$ of the income range of the second income category $(=(12,175-9522) /(19,845-9522))$. Now, a ballpark estimate for the share of precarious solo self-employed can be computed by taking $25.7 \%$ in between the lower and upper bound according to each indicator. For the unemployed indicator, this amounts to $0.065+0.257 \times(0.196-0.065)=0.099$. For Necessityl, this amounts to $0.051+0.257 \times(0.155-0.051)=0.078$. Finally, for necessity 2 , this amounts to $0.042+0.257 \times(0.158-0.042)=0.072$.
}

\subsection{Testing the hypothesis}

In order to test hypothesis 1 , we estimate a regression model. The specific structure of our data set (in particular the low number of waves, which is just two in our case) requires us to adopt Mundlak's (1978) approach to estimate several quasi fixed effects (QFE) models. In practice, this approach comprehends replacing the usual individual fixed effects (FE) with a set of time-invariant regressors, which are computed as the individualspecific averages over time (these regressors are denoted as $\bar{w}_{i}^{\prime}$. in Eq. (1) below). ${ }^{10}$ These auxiliary, timeinvariant regressors are constructed and added to the model only for those regressors that vary over time. Hence, whereas in a normal FE model the crosssectional variation is captured by the fixed effects, it is now captured by the set of time-invariant regressors. The econometric formula is as follows:

$y_{i t}^{*}=x_{i t}^{\prime} \beta+\bar{w}_{i}^{\prime} \cdot \lambda+u_{i t}$

where $y_{i t}^{*}$ is the dependent variable in seven annual turnover categories, $x_{i t}^{\prime}$ is a vector of independent variables, and $\beta$ is a vector of coefficients to be estimated. $\bar{w}_{i}^{\prime}$. denotes the vector of time-invariant regressors (individual-specific averages over time) and the $\lambda \mathrm{s}$ are auxiliary parameters. Finally, $u_{i t}$ is an error term.

Given that our dependent variable is measured as a seven category-variable, our QFE model (1) is estimated using an ordered probit estimator. Furthermore, even though fixed effects estimation is not appropriate (as explained above, we use a QFE model rather than a FE model), we still have a choice between a normal (pooled) ordered probit estimator and a random effects ordered probit estimator to estimate our quasi fixed effects model. In this respect, a Hausman test clearly states that both the random effects (RE) and pooled estimator are appropriate $\left(\chi^{2}=9.830, p=0.631\right)$. Hence, there is no need to use RE ordered probit. Finally, we also cluster standard errors to allow for correlation of the error terms within individuals. To summarize, in order to estimate our quasi fixed effects model (1), we use the pooled ordered probit estimator with clustered robust standard errors. The pooled ordered probit estimator, in turn, is executed using maximum likelihood estimation. Hypothesis 1 is tested by

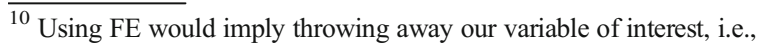
the start-up motive, as this variable does not vary over time.
} 
Table 2 Frequency and percentage of solo self-employed without sufficient alternative income sources to make ends meet, per annual turnover category and by necessity indicator

\begin{tabular}{|c|c|c|c|c|c|c|}
\hline \multirow[t]{2}{*}{ Annual turnover } & \multicolumn{3}{|l|}{ Frequency } & \multicolumn{3}{|l|}{ Percent } \\
\hline & Opportunity & Necessity & Total & Opportunity & Necessity & Total \\
\hline \multicolumn{7}{|l|}{ Unemployed* ${ }^{*}$} \\
\hline Less than 10,000 euro & 59 & 7 & 66 & 7.1 & 12.5 & 7.4 \\
\hline 10,000 up to 25,000 euro & 146 & 14 & 160 & 17.6 & 25.0 & 18.0 \\
\hline 25,000 up to 50,000 euro & 215 & 18 & 233 & 25.8 & 32.1 & 26.2 \\
\hline 50,000 up to 100,000 euro & 244 & 9 & 253 & 29.3 & 16.1 & 28.5 \\
\hline 100,000 up to 200,000 euro & 131 & 8 & 139 & 15.8 & 14.3 & 15.7 \\
\hline 200,000 up to 500,000 euro & 32 & 0 & 32 & 3.9 & 0.0 & 3.6 \\
\hline More than 500,000 euro & 5 & 0 & 5 & 0.6 & 0.0 & 0.6 \\
\hline Total & 832 & 56 & 888 & 100.0 & 100.0 & 100.0 \\
\hline \multicolumn{7}{|l|}{ Necessityl $* *$} \\
\hline Less than 10,000 euro & 42 & 24 & 66 & 6.4 & 10.3 & 7.4 \\
\hline 10,000 up to 25,000 euro & 111 & 49 & 160 & 16.9 & 21.1 & 18.0 \\
\hline 25,000 up to 50,000 euro & 164 & 69 & 233 & 25.0 & 29.7 & 26.2 \\
\hline 50,000 up to 100,000 euro & 194 & 59 & 253 & 29.6 & 25.4 & 28.5 \\
\hline 100,000 up to 200,000 euro & 114 & 25 & 139 & 17.4 & 10.8 & 15.7 \\
\hline 200,000 up to 500,000 euro & 26 & 6 & 32 & 4.0 & 2.6 & 3.6 \\
\hline More than 500,000 euro & 5 & 0 & 5 & 0.8 & 0.0 & 0.6 \\
\hline Total & 656 & 232 & 888 & 100.0 & 100.0 & 100.0 \\
\hline \multicolumn{7}{|l|}{ Necessity2*** } \\
\hline Less than 10,000 euro & 47 & 19 & 66 & 6.9 & 9.1 & 7.4 \\
\hline 10,000 up to 25,000 euro & 108 & 52 & 160 & 15.9 & 25.0 & 18.0 \\
\hline 25,000 up to 50,000 euro & 170 & 63 & 233 & 25.0 & 30.3 & 26.2 \\
\hline 50,000 up to 100,000 euro & 208 & 45 & 253 & 30.6 & 21.6 & 28.5 \\
\hline 100,000 up to 200,000 euro & 115 & 24 & 139 & 16.9 & 11.5 & 15.7 \\
\hline 200,000 up to 500,000 euro & 28 & 4 & 32 & 4.1 & 1.9 & 3.6 \\
\hline More than 500,000 euro & 84 & 1 & 5 & 0.6 & 0.5 & 0.6 \\
\hline Total & 680 & 208 & 888 & 100.0 & 100.0 & 100.0 \\
\hline
\end{tabular}

$* \chi^{2}=10.274, p=0.114 ; * * \chi^{2}=15.205, p=0.019 ; * * * \chi^{2}=36.054, p=0.000$

evaluating the sign and statistical significance of the necessity dummy indicators in models (2-4).

\section{Results}

\subsection{Estimates and marginal effects}

Table 3 presents the results of the regression analysis. The base model includes all control variables but does not include our indicator variables for necessity solo self-employment. In models $2-4$, these indicators are then added to the baseline model. The estimation results are based on a sample of 1360 solo self-employed corresponding to 1803 observations. Likelihood ratio tests show that, by adding the indicator variables to the base model, annual turnover is better predicted.

All three necessity indicator variables are significant and show a negative relation with annual turnover, thereby supporting hypothesis 1 . The magnitude of the effects can be shown by using marginal effects (see Table 4). In line with the general coefficients in Table 3, the marginal effects of necessity entrepreneurship are positive for the lower income categories and negative for the higher income categories. Regarding the lower income categories, it can be seen that, for the 


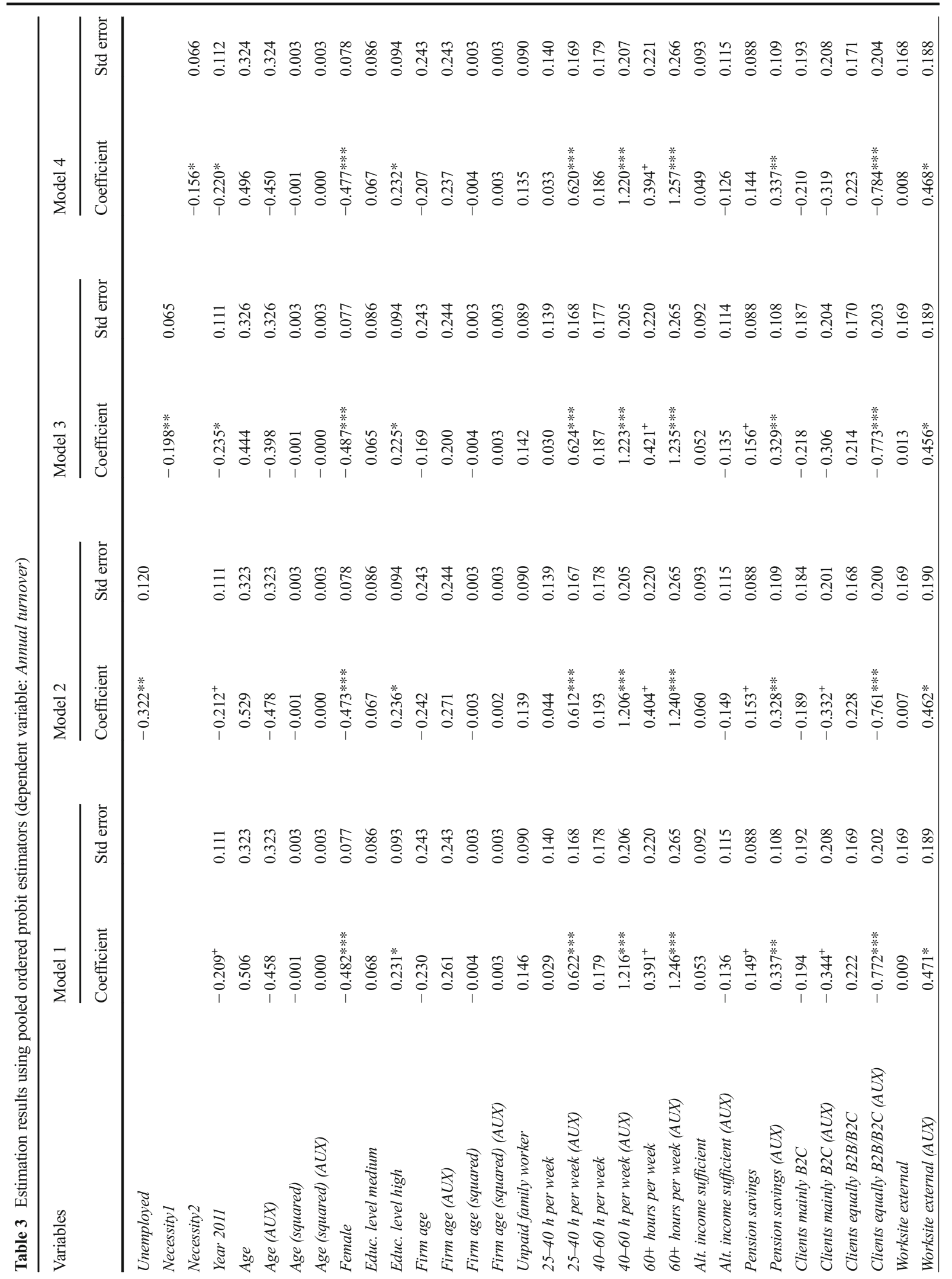


unemployment indicator, the necessity solo selfemployed have an 11.6 percentage point higher probability to earn 25,000 or less (compared with opportunity solo self-employed), while this probability is 6.8 and 5.3 percentage point higher for the Necessityl and Necessity2 indicators, respectively. However, when taking a stricter, and arguably more realistic poverty criterion, i.e., the lowest income category $(<10,000$ euro), the probability of falling in this lowest income category is only 4.4, 2.3 and 1.8 percentage point higher for necessity solo self-employed compared with opportunity solo self-employed. For the highest income categories, the difference between opportunity and necessity-driven solo self-employed is almost negligible. In our view, Table 4 illustrates that the difference in income distributions of necessity and opportunity-driven solo selfemployed is smaller than might have been expected given earlier literature stressing the negative aspects of necessity entrepreneurship (e.g., Acs 2006).

Regarding the control variables in Table 3, we note a strong negative relation for females. Also, a high educational level is positively associated with a higher annual turnover, as expected. We also find a positive relation with annual turnover for the number of working hours and for pension savings. By and large, results for our control variables are according to expectations.

\section{Conclusions}

This paper investigated the relationship between start-up motivation (opportunity versus necessity) and entrepreneurial performance of an important subset of entrepreneurs, viz., the solo self-employed. We used a unique individual-level panel data set of solo self-employed in the Netherlands for two consecutive years (2010-2011) and constructed three separate measures derived from the literature to identify necessity-driven solo self-employment. Using annual turnover as measure of entrepreneurial performance, we found, for each of the three measures, that necessity-driven solo self-employed perform worse than opportunity-driven solo self-employed. Still, we also found that only a low proportion of necessity solo self-employment may be considered precarious employment.

Our research has several implications for research and policy. Regarding research implications, earlier research has shown that solo self-employed and selfemployed with personnel have different motivations to 
Table 4 Marginal effects per annual turnover category by necessity indicator

\begin{tabular}{|c|c|c|c|c|c|c|}
\hline \multirow[t]{2}{*}{ Annual turnover } & \multicolumn{2}{|l|}{ Unemployed } & \multicolumn{2}{|l|}{ Necessityl } & \multicolumn{2}{|l|}{ Necessity2 } \\
\hline & Marg effect & Std error & Marg effect & Std error & Marg effect & Std error \\
\hline Less than 10,000 euro & $0.044 *$ & 0.020 & $0.023 * *$ & 0.008 & $0.018^{*}$ & 0.008 \\
\hline 10,000 up to 25,000 euro & $0.072 * *$ & 0.026 & $0.045^{* *}$ & 0.025 & $0.035^{*}$ & 0.015 \\
\hline 25,000 up to 50,000 euro & -0.003 & 0.007 & $0.005 *$ & 0.002 & $0.004 *$ & 0.002 \\
\hline 50,000 up to 100,000 euro & $-0.069 * *$ & 0.026 & $-0.042 * *$ & 0.014 & $-0.033 *$ & 0.014 \\
\hline 100,000 up to 200,000 euro & $-0.038 * * *$ & 0.012 & $-0.026^{* *}$ & 0.008 & $-0.021^{*}$ & 0.009 \\
\hline 200,000 up to 500,000 euro & $-0.005^{* *}$ & 0.002 & $-0.004 * *$ & 0.001 & $-0.003 *$ & 0.001 \\
\hline More than 500,000 euro & $-0.000 *$ & 0.000 & $-0.000^{+}$ & 0.000 & $-0.000^{+}$ & 0.000 \\
\hline
\end{tabular}

Marginal effects correspond to the estimation results of models 2, 3, and 4 in Table 3, respectively. Marginal effects relate to a discrete change from zero to one. Significance levels: ${ }^{+} 0.05<p \leq 0.10 ; * 0.01<p \leq 0.05 ; * * 0.001<p \leq 0.01 ; * * * p \leq 0.001$

run a business (Parker 2004: 80; Petrescu 2016). An implication of our study is that, in addition, it is also important to distinguish between motivations within the population of solo self-employed to understand their entrepreneurial performance.

Regarding policy implications, we find significant but moderate differences between the entrepreneurial performance of necessity and opportunity solo selfemployed. Specifically, our estimations imply that the probability of making an annual turnover of less than 10,000 euros is 1.8 to 4.4 percentage point higher for necessity solo self-employed compared with their opportunity counterparts, depending on the indicator for necessity motive. We also find that, among necessity solo self-employed, only a small proportion (our ballpark estimate is 7 to $10 \%$ ) may be considered precarious employment, in the sense of making a low income from solo self-employment (below the "at-risk-of-poverty" threshold as defined by Eurostat) without having sufficient alternative income sources to make ends meet in case the business income falls out. These results can therefore lead to different policy implications depending on the policy motives at play. When stimulating economic growth is the objective, it can be advisable to not encourage start-ups with necessity motives. On the other hand, from a more social-economic point of view, these necessity-driven activities still provide a certain level of subsistence and may lower social welfare expenditures and the total costs for society. From this perspective, necessity entrepreneurship may not be so worrisome as sometimes assumed. This perspective is further supported by our finding that the overlap between our three necessity indicators is only moderate, suggesting that the borderline between necessity and opportunity entrepreneurship in developed economies is less clear-cut than previously assumed.

Our paper has a number of limitations. First, the data set is unbalanced, because of participating panelists dropping out and the sample being complemented with new respondents on an annual basis. The exact reasons for panelists not participating (anymore) remain unclear. Some simple tests suggested that the extent of attrition bias may be limited though. Still, we cannot exclude the possibility that there is a slight bias on both ends of the income distribution, as the lowest performing solo selfemployed may select out of the panel via firm exit and the highest performing solo self-employed via employing personnel. Second, the average number of observations per individual is less than one and a half. Ideally, one would have had a larger number of observations per solo self-employed. In that case we would have been able to better explore the dynamics over time of both types of solo self-employed. We accommodated for the short time span by using a Mundlak approach, though. Third, we cannot exclude the possibility that, to some extent, our results are influenced by the (crisis) years of our data set, 2010-2011. In other words, it is not straightforward to generalize our results to non-crisis contexts. Fourth, one of our measures of necessity solo self-employment (Necessity2) is based on answers that could also be interpreted in terms of push versus pull motivation rather than strictly necessity versus opportunity.

Future research may focus on replicating our results (e.g., for different countries or business cycles), to see if our results can be generalized to other contexts 
(Davidsson 2015). Future research may also focus on other performance indicators, e.g., the extent of innovativeness of solo self-employed (both product and process innovation) and levels of growth ambition. Finally, future research could also focus on further conceptualization of the opportunity versus necessity dichotomy.

Acknowledgments The authors would like to thank Andrew Burke, Arthur van Soest, Erik Stam, and two anonymous referees for their useful comments.

Funding information The research has been supported by the "Research Program on SMEs and Entrepreneurship," financed by the Dutch Ministry of Economic Affairs. The data set used in this paper has been partly funded by the Dutch Ministry of Social Affairs and Employment. In addition, the research has also been supported by Research Project no. 2015/19/B/HS4/00366 (Selfemployment from Polish and international perspective) funded by the National Science Centre of Poland.

Open Access This article is distributed under the terms of the Creative Commons Attribution 4.0 International License (http:// creativecommons.org/licenses/by/4.0/), which permits unrestricted use, distribution, and reproduction in any medium, provided you give appropriate credit to the original author(s) and the source, provide a link to the Creative Commons license, and indicate if changes were made.

\section{References}

Acs, Z. (2006). How is entrepreneurship good for economic growth? Innovations, 1(1), 97-107. https://doi.org/10.1162 /itgg.2006.1.1.97.

Acs, Z. J., \& Varga, A. (2005). Entrepreneurship, agglomeration and technological change. Small Business Economics, 24(3), 323-334. https://doi.org/10.1007/s11187-005-1998-4.

Arum, R., \& Müller, W. (Eds.). (2004). The reemergence of selfemployment: a comparative study of self-employment $d y$ namics and social inequality. Princeton: Princeton University Press.

Baptista, R., Karaöz, M., \& Mendonça, J. (2014). The impact of human capital on the early success of necessity versus opportunity-based entrepreneurs. Small Business Economics, 42(4), 831-847. https://doi.org/10.1007 /s11187-013-9502-z.

Baumgartner, H. J., \& Caliendo, M. (2008). Turning unemployment into self-employment: Effectiveness of two start-up programmes. Oxford Bulletin of Economics and Statistics, 70(3), 347-373. https://doi.org/10.1111/j.14680084.2008.00505.x.

Blanchflower, D. G., \& Oswald, A. J. (1998). What makes an entrepreneur? Journal of Labor Economics, 16(1), 26-60. https://doi.org/10.1086/209881.
Block, J. H., Kohn, K., Miller, D., \& Ullrich, K. (2015). Necessity entrepreneurship and competitive strategy. Small Business Economics, 44(1), 37-54. https://doi.org/10.1007/s11187014-9589-x.

Block, J. H., \& Sandner, P. (2009). Necessity and opportunity entrepreneurs and their duration in self-employment: Evidence from German micro data. Journal of Industry, Competition and Trade, 9(2), 117-137. https://doi. org/10.1007/s10842-007-0029-3.

Block, J. H., \& Wagner, M. (2010). Necessity and opportunity entrepreneurs in Germany: characteristics and earnings differentials. Schmalenbach Business Review, 62(2), 154-174. https://doi.org/10.1007/bf03396803.

Bögenhold, D., \& Fachinger, U. (2012). How diverse is entrepreneurship? Observations on the social heterogeneity of selfemployment in Germany. In J. Bonnet, M. Dejardin, \& A. Madrid-Guijarro (Eds.), The shift to the entrepreneurial society: a built economy in education, sustainability and regulation (pp. 227-241). Cheltenham: Edward Elgar Publishing Limited.

Brewer, J., \& Gibson, S. W. (2014). Necessity entrepreneurs: microenterprise education and economic development. Cheltenham/ Northampton: Edward Elgar Publishing.

Burke, A. E. (2011). The entrepreneurship enabling role of freelancers: theory with evidence from the construction industry. International Review of Entrepreneurship, 9(3), 131-158.

Burke, A. E. (2012). The role of freelancers in the 21st century British economy. London: Professional Contractors Group Ltd.

Burke, A. E., \& Cowling, M. (2015). The use and value of freelancers: the perspective of managers. International Review of Entrepreneurship, 13(1), 7-20.

Caliendo, M., Hogenacker, J., Künn, S., \& Wießner, F. (2015). Subsidized start-ups out of unemployment: a comparison to regular business start-ups. Small Business Economics, 45(1), 165-190. https://doi.org/10.1007/s11187-015-9646-0.

Caliendo, M., \& Kritikos, A. S. (2009). I want to, but I also need to - start-ups resulting from opportunity and necessity. DIW Berlin Discussion Paper no. 966. Retrieved from https://papers.ssrn.com/sol3/papers.cfm?abstract_ $\mathrm{id}=1592904$. Accessed 30 April 2019.

Cieślik, J., \& van Stel, A. (2014). Comparative analysis of recent trends in private sector development in CEE transition economies. Entrepreneurship Research Journal, 4(2), 205-235. https://doi.org/10.1515/erj-2013-0054.

CRSE. (2017). The true diversity of self-employment. London: Centre for Research on Self-Employment.

Darnihamedani, P., \& Hessels, J. (2016). Human capital as a driver of innovation among necessity-based entrepreneurs. International Review of Entrepreneurship, 14(1), 1-24.

Davidsson, P. (2015). Data replication and extension: a commentary. Journal of Business Venturing Insights, 3, 12-15. https://doi.org/10.1016/j.jbvi.2015.02.001.

Dawson, C., \& Henley, A. (2012). "Push" versus "pull” entrepreneurship: an ambiguous distinction? International Journal of Entrepreneurial Behavior \& Research, 18(6), 697-719. https://doi.org/10.1108/13552551211268139.

Eurostat. (2013). The measurement of poverty and social inclusion in the EU: Achievements and further improvements. UNECE working paper 25. Paper presented at the conference for 
European statisticians, 2-4 December (p. 2013). Switzerland: Geneva.

Eurostat. (2016). At-risk-of-poverty-threshold - EU-SILC survey. Retrieved from: http://appsso.eurostat.ec.europa. eu/nui/show.do?dataset=ilc_li01\&lang=en. Accessed 15 Dec 2016.

Fossen, F. M., \& Büttner, T. J. M. (2013). The returns to education for opportunity entrepreneurs, necessity entrepreneurs, and paid employees. Economics of Education Review, 37, 66-84. https://doi.org/10.1016/j.econedurev.2013.08.005.

Fritsch, M., Kritikos, A. S., \& Sorgner, A. (2015). Why did selfemployment increase so strongly in Germany? Entrepreneurship and Regional Development, 27(5-6), 307-333. https://doi.org/10.1080/08985626.2015.1048310.

Giacomin, O., Janssen, F., Guyot, J.-1., \& Lohest, O. (2011). Opportunity and/or necessity entrepreneurship? The impact of the socio-economic characteristics of entrepreneurs. MPRA Paper No. 29506. Munich: MPRA Retrieved from https://mpra.ub.uni-muenchen.de/29506/. Accessed 1 Oct 2015.

Henrekson, M., \& Sanandaji, T. (2014). Small business activity does not measure entrepreneurship. Proceedings of the National Academy of Sciences, 111(5), 1760-1765. https://doi.org/10.1073/pnas.1307204111.

Kautonen, T., \& Palmroos, J. (2010). The impact of a necessitybased start-up on subsequent entrepreneurial satisfaction. International Entrepreneurship and Management Journal, 6(3), 285-300. https://doi.org/10.1007/s11365-008-0104-1.

Kher, R., Streeter, D. H., \& Just, D. R. (2012). The "good job" trap: opportunity cost as a deterrent to immediate venture creation. International Review of Entrepreneurship, 10(4), $127-152$.

Kitching, J. (2015). Tracking UK freelance workforce trends 1992-2015. International Review of Entrepreneurship, 13(1), 21-34.

Larsson, J. P., \& Thulin, P. (2018). Independent by necessity? The life satisfaction of necessity and opportunity entrepreneurs in 70 countries. Small Business Economics, Advance online publication. https://doi.org/10.1007/s11187-018-0110-9.

Luber, S., \& Leicht, R. (2000). Growing self-employment in Western Europe: an effect of modernization? International Review of Sociology, 10(1), 101-123. https://doi.org/10.1080 1713673991.

Mason, C., \& Brown, R. (2014). Entrepreneurial ecosystems and growth oriented entrepreneurship: final report to OECD. Paris: OECD.

Mundlak, Y. (1978). On the pooling of time series and cross section data. Econometrica, 46(1), 69-85. https://doi. org/10.2307/1913646.

OECD. (2000). Employment outlook: June 2000. Paris: OECD.

Parker, S. C. (2004). The economics of self-employment and entrepreneurship. Cambridge: Cambridge University Press.
Petrescu, M. (2016). Self-employed individuals with and without employees: Individual, social and economic level differences. International Review of Entrepreneurship, 14(3), 289-312.

Poschke, M. (2013). 'Entrepreneurs out of necessity': a snapshot. Applied Economics Letters, 20(7), 658-663. https://doi. org/10.1080/13504851.2012.727968.

Rapelli, S. (2012). European I-Pros: a study. London: Professional Contractors Group Ltd., English language version.

Reynolds, P. D., Camp, S. M., Bygrave, W. D., Autio, E., \& Hay, M. (2002). Global Entrepreneurship Monitor, 2001 executive report. Wellesley/ London/ Kansas City: Babson College/ London Business School/ Kauffman Center for Entrepreneurial Leadership.

Román, C., Congregado, E., \& Millán, J. M. (2011). Dependent self-employment as a way to evade employment protection legislation. Small Business Economics, 37(3), 363-392. https://doi.org/10.1007/s11187-009-9241-3.

Smeaton, D. (2003). Self-employed workers: calling the shots or hesitant independents? A consideration of the trends. Work, Employment and Society, 17(2), 379-391. https://doi. org/10.1177/0950017003017002008.

Stam, E. (2014). The Dutch entrepreneurial ecosystem. SSRN Electronic Journal. Retrieved from https://papers.ssrn. com/sol3/papers.cfm?abstract_id=2473475. https://doi. org/10.2139/ssrn.2473475. Accessed 25 June 2018.

Taylor, M. P. (1996). Earnings, independence or unemployment: why become self-employed? Oxford Bulletin of Economics and Statistics, 58(2), 253-266. https://doi.org/10.1111 /j.1468-0084.1996.mp58002003.x.

Turkina, E., \& Thai, M. T. T. (2015). Socio-psychological determinants of opportunity entrepreneurship. International Entrepreneurship and Management Journal, 11(1), 213238. https://doi.org/10.1007/s11365-013-0288-x.

Van Stel, A., \& De Vries, N. (2015). The economic value of different types of solo self-employed: a review. International Review of Entrepreneurship, 13(2), 73-80.

van Stel, A., Millán, A., Millán, J. M., \& Román, C. (2018). The relationship between start-up motive and earnings over the course of the entrepreneur's business tenure. Journal of Evolutionary Economics, 28(1), 101-123. https://doi. org/10.1007/s00191-017-0499-3.

Williams, N., \& Williams, C. C. (2014). Beyond necessity versus opportunity entrepreneurship: some lessons from English deprived urban neighbourhoods. International Entrepreneurship and Management Journal, 10(1), 23-40. https://doi.org/10.1007/s11365-011-0190-3.

Publisher's note Springer Nature remains neutral with regard to jurisdictional claims in published maps and institutional affiliations. 